\title{
Influence of Personality and Learning Styles in English Language Achievement
}

\author{
Rajib Ahmed Faisal \\ Institute of Education and Research, University of Chittagong, Chittagong, Bangladesh \\ Email: faisal.ier@cu.ac.bd
}

How to cite this paper: Faisal, R.A. (2019) Influence of Personality and Learning Styles in English Language Achievement. Open Journal of Social Sciences, 7, 304-324. https://doi.org/10.4236/jss.2019.78022

Received: August 14, 2019

Accepted: August 20, 2019

Published: August 23, 2019

Copyright (C) 2019 by author(s) and Scientific Research Publishing Inc. This work is licensed under the Creative Commons Attribution-NonCommercial International License (CC BY-NC 4.0). http://creativecommons.org/licenses/by-nc/4.0/ cc) (i) (8) Open Access

\begin{abstract}
Reconnoitering the factors that may impact the academic achievement of learners is relevant for instructional scientists. The absence of knowledge of this likely connection with teachers and learners can lead to discouragement of the further perseverance of language learners. The present study seeks to define the prevalence of personality types and learning styles in Bangladeshi context as well as to address the impact of traits and styles on the samples ( $\mathrm{N}$ =676). A cross-sectional quantitative research design was used for this study and self-reported BFI questionnaire, VARK questionnaire and an achievement test were used for collecting relevant data. Analysis of data shows that Agreeable is the most dominant trait for both boys and girls. Again, boys prefer multiple learning styles (multimodal) whereas girls prefer Auditory. In this study, some demographic factors, personality traits and learning styles of the learners were discovered to have an important connection with GPA. Study results indicate that there is a statistically significant association between Multimodal and academic achievement. At the same time, the relationship between the trait extraversion and EFL learners, English language achievement is also found statistically significant. The results of the research questions are highly expected to offer educators some idea of amending the country's state of affairs in terms of EFL teaching and learning not just in Bangladesh but in other non-English nations as well. Further study can be done in exploring the learning styles and personality traits of the teachers as it is observed in previous studies that these are significantly related to the academic excellence.
\end{abstract}

\section{Keywords}

Personality Trait, Learning Styles, EFL Learners, English Language, Achievement 


\section{Background}

Probably the shortest question that has an immense answer is "How do people learn?" Some learn thoughtfully whilst others process information more superficially and they differ in their information processing, organizing, recalling and applying [1]. Research discovered that teaching-learning processes are acted upon by a number of variables while some are extraneous and some are inherent. External elements such as classroom type, learning techniques, school place, learning equipment, teacher experience, and so on had been given a lot of consideration. An individual's emotion, attitude, and behavioral reaction patterns that are deemed to be inner variables are estimated to have an important effect on the teaching-learning process. A particular combination of an individual's pattern of emotion, attitude, and behavioral reaction that makes an individual special is called personality [2] and is compatible throughout their lives. Again, learning style is both an individual feature and a preferred way of acquiring information. Characteristics of personality form a significant part of learning styles as they are so intertwined [3].

The quality of the thinking of learners is critical to learning, and their academic achievement could possibly be ascertained [1]. Educational achievement is a prime concern for learners, teachers, parents, school administrators, and the wider community [4]. Researchers have tried to untangle the intricacies about educational achievement and many reasons for variations in achievement have been placed forward by the psychologists. The research found that cognitive ability is not solely adequate for student to succeed in academics [5]. Developing self-conception among learners might influence their academic achievement, but it is quite worrying that most of them currently have low self-conceptions and are also passive and negative [6]. Chamorro-Premuzic \& Furnam [5] conducted a research which showed that cognitive ability is not solely adequate for student to succeed in academics and these results broadened the researchers' interest in identifying the non-cognitive predictors of academic achievement. In affecting academic success, personality and learning styles are both probable to play important roles.

\subsection{Big Five Model}

Interest in personality studies has risen over the previous few centuries, so personality psychologists have created a measuring tool called the Five Factor Model (FFM) Personality Inventory using factor analysis based on adjective-driven issues [7]. Researchers decided to use a prevalent language in the early 1980s, so they defined personality through a five-factor model called the "Big Five" [8] which describe the personality traits of an individual.

The five main features of the Big Five are: Openness to Experience, Awareness, Extraversion-Introversion, Compatibility, and Neuroticism-Emotional Stability [9]. The acronym OCEAN is used to describe them. According to Gosling, et al. [10] Big-Five Framework is a hierarchical classification model of personality traits with five wide variables representing personality at the widest abstraction 
level. Each Big-Five Framework Janus-faced factor (e.g., Extraversion: outgoing vs. reserved) recapitulates several more particular facets (e.g., sociableness), which in turn subsumes a big amount of even more particular features (e.g., speech, outgoing) [11]. It is therefore possible to classify the most individual differences in human character into five wide, empirically derived domains [12].

\subsection{VARK Model}

Various educators, psychologists and scientists have studied the notion of teaching-learning styles, whereas learning styles is a word used to advert to data collection, handling, interpretation, organization and thinking techniques. In education there are many models of learning styles, such as Howard Gardner's Multiple Intelligences Theory (1999), David Kolb's Learning Styles (1984), Albert Bandura's Theory (1977), Carl Jung's Theory of Personality Types (1921) [13]. How people learn and interact best can be evaluated using a simple VARK inventory, but not a learning style, a measuring tool that focuses on how individuals' best receive data and how individuals' best communicate. VARK is the acronyms of individuals' visual, auditory, read/write and kinesthetic learning styles. Neil D. Fleming, an educator for more than forty years, developed the VARK scale from 1987 [14], which is a simple sixteen-question test with four alternatives, each and the participants could choose more than one choice if they discovered it appropriate. The scale uses real world questions in dynamic settings. According to the VARK, multimodal is considered as another form of learning style when an individual learns with two or more ways of learning. Multimodalities are used in most learning with students accessing one or more strategies that specifically benefit them. According to Fleming [15] multimodalities refer to the profile having some $\mathrm{V}$, some $\mathrm{A}$, some $\mathrm{R}$, and some $\mathrm{K}$, but in their profile some may have greater methods than others.

\subsection{Personality and EFL Learning}

The discovery of the Big Five personality variables in linguistic information resulted in the structural assessment of questionnaires and other personality tools, tools that may or may not be specifically intended to evaluate these factors [16]. According to Asghari et al. [17] EFL students have some perceptions of their learning and these opinions are affected by many factors, such as individual differences and specific personality characteristics. The ample amount of research on personality and its impact on EFL learning has been conducted. Various scientists performed research with distinct methods and focused on distinct fields of character personality traits. Ehrman [18] revealed extra outcomes demonstrating personality relationships, language learning ability, language learning, and program structure for language learning.

\subsection{Learning Styles and EFL Learning}

Students and learners of the EFL language do not likewise receive new data. Just as we look, behave and feel differently, so we are distinct in the manner we learn. 
Every individual has a style of learning. Students have distinct learning styles, which is the reason for the diversity of how learners acquire a foreign language, such as English, seen in schools. Language learning strategies are learners' particular behaviors or methods that facilitate any portion of their own language development [19]. According to Oxford ([20]: p. 42) language learners need to use familiar strategies linked to their styles to create the most of their comfortable style choices; again, they also need to extend beyond their "Stylistic Comfort Area" to use teaching strategies that may not feel correct at first. Yufrizal \& Holiday [21] suggest that learning style is a significant factor in a number of fields, including academic achievement of learners, how learners learn and teachers teach, and communication between learners and educators. VARK encourages the concept that learners can learn in various ways, provided that teaching techniques are suitable to the preferences of the learners [22].

\subsection{Personality, Learning Styles and Academic Achievement}

Since the end of the twentieth century, how personality correlates with academic performance has become increasingly interesting and many studies are undertaken in distinct country contexts on personality traits, learning styles and English language accomplishment [23]. Sadeghi et al. [24] said that personality traits and learning styles are interwoven and function on a continuum so that personality forms a significant dimension of learning styles. A powerful tie between personality traits and teaching styles has been discovered by many researchers. Busato, et al. [25] (as cited in, [26]) found a significant correlation between personality types and styles of learning. Two British university specimens in three longitudinal studies, Chamorro-Premuzic \& Furnam [5] performed a survey to explore the connection between personality characteristics and academic achievement and discovered a substantial connection between personality and academic accomplishment. Pornsakulvanich, et al. [27] acknowledged that ample of research unveil that there lies a strong relationship between personality traits and academic performance. Traits of personality have a beneficial or negative effect on learners' academic accomplishment [4]. Nye, et al. [28] investigated interrelations between psychological peculiarities, measured by Big Five model and their academic performances. The study found positive and significant correlation between the five types of personality (openness, consciousness, extraversion agreeableness and neuroticism) and students' educational achievements.

\subsection{English Language Teaching and Learning in Bangladesh}

In this age of globalization, English has created itself as a worldwide language as it is able to create a unique position that is acknowledged in every nation. English has accomplished this worldwide status because nations either make it an official language or give unique priority to studying it as a foreign language [29]. According to Crystal [29] an estimated 337 million individuals learned English as a first language (L1) and an estimated 235 million individuals learned English as a second language (L2). English is also the most extensively studied contem- 
porary languages in the globe [30]. In 1990, Bangladesh's government took an initiative to introduce English as a mandatory subject from grade I. The new syllabus and fresh books were introduced in the year 1992. English was subsequently taught in Bangladesh as a mandatory language topic from primary to tertiary level (Bachelor's degree) in general education and madrasahs.

Secondary education in Bangladesh includes grades 6 through 12 education or the second phase of education that begins after primary education and continues to higher education begins. English is a major foreign language course in all of the country's high school grades. The nation has shifted from a long-term Grammar Translation Method to a Communicative Language Teaching (CLT) method for EFL teaching [31]. However, ELT attempts seem to be comparatively inadequate and insufficient in view of the worldwide demand for time and motion.

\subsection{Present Study}

Al-Qaisy \& Khuffash [32] reported that education is a distinctive investment and an important aspect of it is academic accomplishment. Academic achievements or academic performances of the students have always been the major concerned about the teachers, students and parents. That is why personality traits and learning styles should be considered in the education arena. For learners of distinct ages, acquiring foreign language, like English, is quite difficult. It is connected with various variables such as era, gender, personality, learning styles. Therefore, the focus of my research interest is how personality and learning style influence the academic performance of the secondary school students of Bangladesh who learn English as a Foreign Language (EFL). The significant relationship between the traits, styles and academic achievement were reported in earlier studies, but none of them were carried out by the EFL learners. Hence this research is an attempt to fill this coffer.

The education policy makers, teachers and parents should study personality in order to comprehend the learning requirements and identify the individual learning style and create strategies for learning and teaching purposes which will provide learners with a more fruitful learning and educational setting. This study will generate a significant body of empirical data, which will lead to greater understanding of how personality traits and learning style relate to the academic achievement of EFL learner's academic achievement. Teacher educators, student teachers and current teachers of Bangladesh can gain valuable direction from the findings of this research ameliorate their own teaching styles. The findings will also show a chance for educators to evaluate themselves about their role in the learning system, reflect on their own instruction styles, and give them a precious understanding that could make them even better teachers in the future.

\section{Material and Methods}

\subsection{Study Focus}

What types of personality traits and learning styles does exist among secondary 
level students of Bangladesh? Are there any significant differences among the learning styles according to school types and school locations? Is there any significant impact of demographic factors, learning styles, and personality traits on English language achievement? Considering these three questions, this research was conducted to investigate the impact of two non-cognitive academic achievement factors (personality traits and learning styles) on Bangladeshi EFL secondary-level learners.

\subsection{Study Design}

For this study, a descriptive research design was adopted in which descriptive research involves surveys and factual results of various types [33]. Survey method was used for this study to collect primary data from the secondary level students of Bangladesh.

\subsection{Study Area}

Because of availability of time, financial supports and communication system, the Researcher selected two districts from Chittagong divisions (Second largest division of the country among seven) for the study to fulfill its purpose.

\subsection{Rationale for Quantitative Approach}

The aim of quantitative research is to collect and generalize numerical data across groups of individuals or explaining a specific phenomenon [34]. In this study, the researcher wanted to explore the influence of personality types and learning styles in educational achievement of EFL learners from secondary level of education in Bangladesh. In such studies, information collection and evaluation methods were more quantitative than qualitative in nature.

\subsection{Population}

Bangladeshi students from main streaming secondary level of Education were considered as the population of this study. According to Bangladesh Bureau of Educational Information and Statistics-BANBEIS [35] there are 204,665 governments, semi-government and non-government secondary schools in the country where 10,475,100 students were enrolled in different grades of secondary level. To collect data, schools as well as students were selected randomly.

\subsection{The Participants}

The overall study was conducted among secondary students of Bangladesh. Thus, all the secondary students are in the sampling frame of the study. By using $n=$ $Z^{2} p q / d^{2}$ formula of sample size was calculated. Using this formula the total of 384 students was selected by taking $50 \%$ prevalence (because the researcher found no reliable source for prevalence for secondary students' personality traits or learning styles from Bangladesh). By adding 0.5 times for the design effect it became $(384+192) 576$ and then considering $20 \%$ non-respondent error the to- 
tal respondent was $(576+115) 691$ and finally, after rounding up the sample were 676. This 676 students from selected four schools (two from each district) were participated chosen as respondents for this study and they were selected randomly during data collection. Class $\mathrm{X}$ was selected purposefully to represent the secondary level. The $29.1 \%$ respondents were from government schools, whereas the rate of semi-government and non-government were $30.4 \%$ and $40.5 \%$ respectively. Most of the (70.7\%) schools were located in urban area. The semi-urban and rural school's percentage were 17.4 and 11.9 respectively. Among the respondents the highest percent (68.3\%) of respondent were female and the rest $(31.7 \%)$ were male.

\subsection{Measures}

The primary strategy for collecting information was engaged using two questionnaires and an achievement test.

\subsubsection{Personality Inventory}

In this study, the Big Five Inventory (BFI) was administered to determine the personality traits of EFL learners for a robust measure of personality traits established by previous researchers John and Srivastava [36]. The BFI was adopted from John et al. [37] consists of forty six items intended to evaluate the big five personality traits, whereas eight statements were for the domain Extraversion and neuroticism, nine for the domain agreeableness and conscientiousness and ten for openness domains. These statements are for self-report and scored according to a five point Likert-type (strongly agree, agree, neutral, disagree and strongly disagree).

\subsubsection{Learning Style Inventory}

There's a lot of techniques available to evaluate styles of learning, with each technique to provide a distinct perspective of the preferences of learning style. The technique used in this research describes the styles of learning preference based on the sensory procedure in which a student likes to acquire new information. In 1987, an educator Neil D. Fleming developed an inventory named $\mathrm{VARK}^{\odot}$ inventory and an updated version was used (version 7.1) for determining the learning style preference of the respondents of this study. The VARK inventory is comprised with 16 items where each item has 4 multiple choice statements.

\subsubsection{Achievement Test}

Level of English language achievement of the students has been confirmed through an achievement test, which is a paper-and-pencil tests in pattern. The test was adapted from the S.S.C. examination, 2017 of the Dhaka Education Board Moreover, the test was finalized with commendation of linguistics experts. The test comprises of 10 items including two free hand writing items. The test was marked out of 60 . In addition, to measure the significance of the test, the researcher also collected the student's most recent marks from their half yearly 
school exams of both English papers.

\subsubsection{Validation and Reliability of the Research Instruments}

The following procedures were performed to assure the validity and reliability of the tools in the preliminary phase. First, the BFI and VARK inventory were translated into Bangla. For the purposes of this study, an expert who had at least five years of proved experience in English translation was asked to consider the complexity and suitability of the inventory text and the language used. Some Bangla wording was adopted based on her feedback to assist, explain the significance of the inventory.

Second, both English I and II question papers of Dhaka Board S.S.C. examination, 2017 were collected and adapted. English experts were then asked to consider the face validity, the validity of the content, and the complexity and suitability of the exam. Experts were characterized as skilled linguistics experts for this assignment, one of them had taught English as a mandatory course at the Institute of Education and Research, University of Dhaka, and another one had at least five years of secondary level EFL teaching experience.

Third, a pilot project was initiated at two Dhaka district schools to evaluate the validity and reliability of the tools and the feasibility of research design and data collection processes. Forty students of Class X, twenty from each school, who learn English as a compulsory subject under national curriculum, participated in the pilot project and they were not intromitted among the research subject. They had to give feedback on the transience and limpidity of the phrasing and directions as well as the appropriateness of the time requirement in accordance with completing the questionnaires and test.

The internal consistency reliability for the BFI questionnaire were adequate (mean $\alpha$ value were 0.70 ) whereas the for the VARK questionnaire $\alpha$ value were 0.58 .

\subsection{Statistical Analysis}

Shapiro-Wilk test, Kolmogrove-Smirnove test, T-test, Post-hoc test (LSD) and stepwise multiple regression analysis were done to analyze the data for addressing the research questions. SPSS 25.0 was used for analyzing data.

\subsection{Ethics}

Prior permission from the school authority as well as the guardian of the respondents were taken. At the same time, the researcher was responsible for data confidentiality and ensuring that the information were not used for any purpose other than that agreed by the respondents. Moreover, the researcher was concerned about not to cause any inconvenience to the scheduled classes during data collection.

\section{Results}

The following sections will demonstrate the findings of the study based on the 
responses of the respondent.

RQ1: What types of personality traits and learning styles exist among secondary level students of Bangladesh?

Among the respondents the highest portion (51.48\%) preferred to learn through a combination of modalities known as Multimodal learning and the lowest portion $(2.81 \%)$ preferred to learn through Visual learning. Besides, the rest of the respondents preferred to learn through Auditory, Read/Write and Kinesthetic, the rate was $19.82 \%, 8.28 \%$ and $17.60 \%$ respectively. Among them the highest rate was observed for the trait Agreeableness and the lowest to Neuroticism, rates were $31.36 \%$ and $4.14 \%$ respectively. Conscientiousness reported to the second highest $(30.77 \%)$ whilst Openness and Extraversion rates were $20.27 \%$ and $13.46 \%$ respectively. English Language Achievement scores mean and SD are $55.28 \pm 19.54$ with a maximum of 98.0 and a minimum of 2.0.

Table 1 shows descriptive statistics of the learning styles, personality traits, and English language achievement. Skewness and kurtosis values from Table 1 suggested the normality of the data. Moreover, $\mathrm{p}$ values of the Shapiro-Wilk test $(p>0.05)$ and Kolmogrove-Smirnove test $(p>0.05)$, and a visual inspection of their normal Q-Q plots suggested the normality of the data. Breussch-Pagan and Koenker test $(p>0.05)$ suggested the homoscedasticity of the data. That is, sample variance was same as population variance.

Table 2 shows that girls are using learning styles like visual $(\mathrm{t}=-2.38, \mathrm{p}<$ $0.05,95 \%$ CI $[-0.55,-0.05]$, effect size $=-0.19)$, auditory $(\mathrm{t}=-4.94, \mathrm{p}<0.01,95 \%$ CI $[-1.21,-0.52]$, effect size $=-0.39)$, read/write $(\mathrm{t}=-5.24, \mathrm{p}<0.01,95 \% \mathrm{CI}$ $[-1.12,-0.51]$, effect size $=-0.42)$, kinesthetic $(\mathrm{t}=-3.78, \mathrm{p}<0.01,95 \% \mathrm{CI}$

Table 1. Descriptive statistics of personality traits, leaning styles and academic achievement of the respondents.

\begin{tabular}{|c|c|c|c|c|c|c|c|}
\hline Variables & Prevalence & M & $\mathrm{SD}$ & Minimum & Maximum & Skewness & Kurtosis \\
\hline \multicolumn{8}{|c|}{ Personality Traits } \\
\hline Openness & 20.27 & 3.67 & 0.54 & 1.30 & 4.90 & -0.55 & 0.57 \\
\hline Consciousness & 30.77 & 3.69 & 0.64 & 1.67 & 5.00 & -0.37 & -0.17 \\
\hline Extraversion & 13.46 & 3.45 & 0.59 & 1.13 & 5.00 & -0.36 & 0.43 \\
\hline Agreeableness & 31.36 & 3.86 & 0.49 & 2.11 & 5.00 & -0.29 & 0.12 \\
\hline Neuroticism & 4.14 & 2.56 & 0.73 & 1.00 & 4.88 & 0.42 & -0.33 \\
\hline \multicolumn{8}{|c|}{ Learning Styles } \\
\hline Visual & 2.81 & 1.93 & 1.58 & 0.00 & 8.00 & 0.82 & 0.71 \\
\hline Auditory & 19.82 & 3.48 & 2.22 & 0.00 & 11.00 & 0.32 & -0.47 \\
\hline Read/Write & 8.28 & 2.52 & 1.97 & 0.00 & 8.00 & 0.48 & -0.59 \\
\hline Kinesthetic & 17.60 & 3.37 & 2.06 & 0.00 & 9.00 & 0.05 & -0.84 \\
\hline Multimodal & 51.48 & 4.68 & 5.44 & 0.00 & 16.00 & 0.72 & -0.95 \\
\hline \multicolumn{8}{|c|}{ Academic Achievement } \\
\hline $\begin{array}{c}\text { English Language } \\
\text { Achievement }\end{array}$ & & 55.28 & 19.54 & 2.00 & 98.00 & -0.36 & -0.63 \\
\hline
\end{tabular}


Table 2. Mean differences in learning styles, personality traits and academic achievement by the respondents' gender.

\begin{tabular}{|c|c|c|c|c|c|c|c|c|}
\hline \multirow{2}{*}{ Variables } & \multicolumn{2}{|c|}{ Boys } & \multicolumn{2}{|c|}{ Girls } & \multirow{2}{*}{$\mathrm{t}$} & \multicolumn{2}{|c|}{$95 \%$ confidence interval } & \multirow{2}{*}{ d } \\
\hline & M & SD & M & SD & & Lower & Upper & \\
\hline \multicolumn{9}{|c|}{ Personality Traits } \\
\hline Openness & 3.69 & 0.58 & 3.66 & 0.52 & 0.53 & -0.06 & 0.11 & 0.06 \\
\hline Conscientiousness & 3.63 & 0.66 & 3.73 & 0.62 & -1.94 & -0.20 & 0.00 & -0.16 \\
\hline Extraversion & 3.33 & 0.59 & 3.51 & 0.58 & $-3.77^{\star \star}$ & -0.27 & -0.08 & -0.31 \\
\hline Agreeableness & 3.79 & 0.54 & 3.89 & 0.45 & $-2.83^{* *}$ & -0.19 & -0.03 & -0.21 \\
\hline Neuroticism & 2.55 & 0.70 & 2.56 & 0.75 & 0.06 & -0.12 & -0.11 & -0.01 \\
\hline \multicolumn{9}{|c|}{ Learning Styles } \\
\hline Visual & 1.74 & 1.65 & 2.034 & 1.53 & $-2.38^{*}$ & -0.55 & -0.05 & -0.19 \\
\hline Auditory & 2.93 & 2.26 & 3.79 & 2.14 & $-4.94^{\star *}$ & -1.21 & -0.52 & -0.39 \\
\hline Read/Write & 2.00 & 1.94 & 2.81 & 1.93 & $-5.24^{\star *}$ & -1.12 & -0.51 & -0.42 \\
\hline Kinesthetic & 2.98 & 2.20 & 3.59 & 1.95 & $-3.78^{* *}$ & -0.94 & -0.30 & -0.30 \\
\hline Multimodal & 6.35 & 5.90 & 3.74 & 4.92 & $6.15^{* *}$ & 1.78 & 3.44 & 0.49 \\
\hline \multicolumn{9}{|c|}{ Academic Achievement } \\
\hline $\begin{array}{c}\text { English Language } \\
\text { Achievement }\end{array}$ & 57.56 & 18.45 & 53.99 & 20.02 & $2.29^{*}$ & 0.50 & 6.63 & 0.18 \\
\hline
\end{tabular}

$[-0.94,-0.30]$, effect size $=-0.30)$ more than boys. Boys are more using multimodal learning strategy $(t=6.15, p<0.01,95 \%$ CI $[1.78,3.44]$, effect size $=0.49)$ than girls. Boys English language achievement is better than girls $(t=2.29, \mathrm{p}<$ $0.05,95 \%$ CI $[0.50,6.63]$, effect size $=0.18)$. Girls belong to the traits like Conscientiousness $(t=-1.94,95 \%$ CI $[-0.06,-0.11]$, effect size $=0.06)$, Extraversion $(\mathrm{t}=-3.77, \mathrm{p}<0.01,95 \% \mathrm{CI}[-0.20,-0.00]$, effect size $=-0.16)$, Agreeableness $(\mathrm{t}$ $=-2.83, \mathrm{p}<0.01,95 \% \mathrm{CI}[-0.19,-0.03]$, effect size $=-0.21)$, Neuroticism $(\mathrm{t}=$ $0.06,95 \%$ CI $[-0.12,-0.11]$, effect size $=-0.01)$, more than boys. Boys belong to Openness $(t=0.53,95 \%$ CI $[-0.06,0.11]$, effect size $=0.06)$ more than girls.

Table 3 shows the sample distribution on school location (urban, semi-urban, and rural), and school types (govt., non-govt., and semi-govt.) regarding learning styles and English language achievement.

RQ2: Are there any significant differences among the learning styles according to school types and school locations?

Table 4 shows significant mean differences in visual $(\mathrm{F}=5.81, \mathrm{p}<0.01$, effect size $=0.13)$, auditory $(\mathrm{F}=14.59, \mathrm{p}<0.01$, effect size $=0.21)$, read/write $(\mathrm{F}=$ 21.12, $\mathrm{p}<0.01$, effect size $=0.25)$, kinesthetic $(\mathrm{F}=16.90, \mathrm{p}<0.01$, effect size $=$ $0.22)$, and multimodal learning $(\mathrm{F}=31.08, \mathrm{p}<0.01$, effect size $=0.30)$ styles, and English language achievement $(\mathrm{F}=74.85, \mathrm{p}<0.01$, effect size $=0.47)$ by school locations. This Table also shows significant mean differences in auditory $(\mathrm{F}=$ 10.62, $\mathrm{p}<0.01$, effect size $=0.18)$, read $/$ write $(\mathrm{F}=18.95, \mathrm{p}<0.01$, effect size $=$ 
Table 3. Descriptive statistics of learning styles and academic achievement by school location and school types.

\begin{tabular}{|c|c|c|c|c|c|c|c|}
\hline \multirow{2}{*}{ Variables } & & \multicolumn{3}{|c|}{ School Location } & \multicolumn{3}{|c|}{ School Types } \\
\hline & & Urban & Semi-urban & Rural & Govt. & Non-govt. & Semi-govt. \\
\hline \multirow{3}{*}{ Visual } & $\mathrm{N}$ & 519 & 93 & 64 & 189 & 263 & 224 \\
\hline & $\mathrm{M}$ & 1.84 & 2.44 & 1.92 & 1.98 & 2.06 & 1.74 \\
\hline & SD & 1.56 & 1.70 & 1.43 & 1.47 & 1.71 & 1.51 \\
\hline \multirow{3}{*}{ Auditory } & $\mathrm{N}$ & 519 & 93 & 64 & 189 & 263 & 224 \\
\hline & $\mathrm{M}$ & 3.34 & 4.59 & 3.02 & 3.72 & 3.78 & 2.93 \\
\hline & $\mathrm{SD}$ & 2.25 & 2.13 & 1.59 & 2.17 & 2.52 & 2.14 \\
\hline \multirow{3}{*}{ Read/Write } & $\mathrm{N}$ & 519 & 93 & 64 & 189 & 263 & 224 \\
\hline & $\mathrm{M}$ & 2.38 & 3.69 & 2.00 & 2.81 & 2.86 & 1.88 \\
\hline & $\mathrm{SD}$ & 1.97 & 1.81 & 1.54 & 1.99 & 1.98 & 1.78 \\
\hline \multirow{3}{*}{ Kinesthetic } & $\mathrm{N}$ & 519 & 93 & 64 & 189 & 263 & 224 \\
\hline & $\mathrm{M}$ & 3.24 & 4.46 & 2.84 & 3.53 & 3.74 & 2.80 \\
\hline & $\mathrm{SD}$ & 2.05 & 1.89 & 1.89 & 2.06 & 2.10 & 1.90 \\
\hline \multirow{3}{*}{ Multimodal } & $\mathrm{N}$ & 519 & 93 & 64 & 189 & 263 & 224 \\
\hline & $\mathrm{M}$ & 5.19 & 0.80 & 6.22 & 3.94 & 3.53 & 6.66 \\
\hline & $\mathrm{SD}$ & 5.62 & 3.06 & 4.10 & 5.41 & 5.36 & 5.01 \\
\hline \multirow{3}{*}{$\begin{array}{c}\text { English Language } \\
\text { Achievement }\end{array}$} & $\mathrm{N}$ & 519 & 93 & 64 & 189 & 263 & 224 \\
\hline & $\mathrm{M}$ & 59.71 & 37.04 & 45.81 & 60.21 & 49.15 & 58.30 \\
\hline & $\mathrm{SD}$ & 17.66 & 20.97 & 11.82 & 18.88 & 21.88 & 14.77 \\
\hline
\end{tabular}

Table 4. Mean differences in learning styles and academic achievement by school location and school types.

\begin{tabular}{|c|c|c|c|c|c|c|c|}
\hline \multirow{2}{*}{ Variables } & \multirow{2}{*}{ Group } & \multicolumn{3}{|c|}{ School Location } & \multicolumn{3}{|c|}{ School Type } \\
\hline & & Mean Square & $\mathrm{F}$ & $f$ & Mean Square & F & $\mathrm{f}$ \\
\hline \multirow{2}{*}{ Visual } & Between & 14.33 & \multirow{2}{*}{$5.81^{\star *}$} & \multirow{2}{*}{0.13} & 6.54 & \multirow{2}{*}{2.63} & \multirow{2}{*}{0.09} \\
\hline & Within & 2.47 & & & 2.49 & & \\
\hline \multirow[b]{2}{*}{ Auditory } & Between & 69.21 & \multirow[b]{2}{*}{$14.59^{* *}$} & \multirow[b]{2}{*}{0.21} & 50.96 & \multirow[b]{2}{*}{$10.62^{* *}$} & \multirow[b]{2}{*}{0.18} \\
\hline & Within & 4.74 & & & 4.80 & & \\
\hline \multirow{2}{*}{ Read/Write } & Between & 77.51 & \multirow{2}{*}{$21.12^{\star *}$} & \multirow{2}{*}{0.25} & 69.95 & \multirow{2}{*}{$18.95^{* *}$} & \multirow{2}{*}{0.24} \\
\hline & Within & 3.67 & & & 3.69 & & \\
\hline \multirow{2}{*}{ Kinesthetic } & Between & 68.68 & \multirow{2}{*}{$16.90^{\star *}$} & \multirow{2}{*}{0.22} & 57.20 & \multirow{2}{*}{$13.96^{* *}$} & \multirow{2}{*}{0.20} \\
\hline & Within & 4.063 & & & 4.097 & & \\
\hline \multirow{2}{*}{ Multimodal } & Between & 843.52 & \multirow{2}{*}{$31.08^{* *}$} & \multirow{2}{*}{0.30} & 664.02 & \multirow{2}{*}{$23.99^{* *}$} & \multirow{2}{*}{0.27} \\
\hline & Within & 27.14 & & & 27.68 & & \\
\hline \multirow{2}{*}{$\begin{array}{c}\text { English Language } \\
\text { Achievement }\end{array}$} & Between & 23437.19 & \multirow{2}{*}{$74.85^{\star *}$} & \multirow{2}{*}{0.47} & 8255.97 & \multirow{2}{*}{$23.05^{\star *}$} & \multirow{2}{*}{0.26} \\
\hline & Within & 313.14 & & & 358.26 & & \\
\hline
\end{tabular}

${ }^{*} \mathrm{p}<0.05,{ }^{*} \mathrm{p}<0.01$. 
$0.24)$, kinesthetic $(\mathrm{F}=13.96, \mathrm{p}<0.01$, effect size $=0.20)$, and multimodal learning $(\mathrm{F}=23.99, \mathrm{p}<0.01$, effect size $=0.27)$ styles, and English language achievement $(\mathrm{F}=23.05, \mathrm{p}<0.01$, effect size $=0.26)$ by school types.

Results of post hoc analysis, in Table 5, show that students from semi-urban schools are using learning styles that were measured more than students from both urban and rural schools. Table 5 also shows that urban school students had better results than students from both semi-urban and rural schools. Rural schools' students had better results for English language than semi-urban schools' students.

Table 5. Post-hoc test (LSD) results of learning styles and English language achievement by school location.

\begin{tabular}{|c|c|c|c|c|c|}
\hline \multirow{2}{*}{ School Location (I) } & \multirow{2}{*}{ School Location (J) } & \multirow{2}{*}{$\mathrm{MD}(\mathrm{I}-\mathrm{J})$} & \multirow{2}{*}{$\mathrm{D}$} & \multicolumn{2}{|c|}{ 95\% Confidence Interval } \\
\hline & & & & Lower & Upper \\
\hline \multicolumn{6}{|c|}{ Visual } \\
\hline \multirow{2}{*}{ Urban } & Semi-urban & $-0.60^{*}$ & -0.38 & -0.95 & -0.26 \\
\hline & Rural & -0.084 & -0.05 & -0.49 & 0.33 \\
\hline \multirow{2}{*}{ Semi-urban } & Rural & $0.52^{*}$ & 0.33 & 0.02 & 1.02 \\
\hline & & Auditory & & & \\
\hline \multirow{2}{*}{ Urban } & Semi-urban & $-1.25^{\star}$ & -0.56 & -1.73 & -0.77 \\
\hline & Rural & 0.33 & 0.15 & -0.24 & 0.90 \\
\hline \multirow[t]{2}{*}{ Semi-urban } & Rural & $1.58^{*}$ & 0.81 & 0.88 & 2.27 \\
\hline & \multicolumn{3}{|c|}{ Read/Write } & & \\
\hline \multirow{2}{*}{ Urban } & Semi-urban & $-1.31^{*}$ & -0.67 & -1.74 & -0.89 \\
\hline & Rural & 0.38 & 0.20 & -0.12 & 0.87 \\
\hline \multirow[t]{2}{*}{ Semi-urban } & Rural & $1.69^{*}$ & 0.99 & 1.08 & 2.30 \\
\hline & & inesthetic & & & \\
\hline \multirow{2}{*}{ Urban } & Semi-urban & $-1.22^{\star}$ & -0.60 & -1.67 & -0.78 \\
\hline & Rural & 0.40 & 0.20 & -0.13 & 0.92 \\
\hline \multirow[t]{2}{*}{ Semi-urban } & Rural & $1.62^{*}$ & 0.86 & 0.98 & 2.26 \\
\hline & & Iultimodal & & & \\
\hline \multirow{2}{*}{ Urban } & Semi-urban & $4.39^{*}$ & 0.83 & 3.24 & 5.54 \\
\hline & Rural & -1.03 & -0.19 & -2.39 & 0.32 \\
\hline \multirow[t]{2}{*}{ Semi-urban } & Rural & $-5.42^{*}$ & -1.54 & -7.08 & -3.76 \\
\hline & \multicolumn{3}{|c|}{ English Language Achievement } & & \\
\hline \multirow{2}{*}{ Urban } & Semi-urban & $22.67^{*}$ & 1.25 & 18.76 & 26.59 \\
\hline & Rural & $13.90^{*}$ & 0.81 & 9.30 & 18.50 \\
\hline Semi-urban & Rural & $-8.77^{\star}$ & 0.49 & -14.42 & -3.13 \\
\hline
\end{tabular}


Table 6 shows that students from government and non-government schools using learning styles that were measured than semi-government schools' students. This Table also shows that government and non-government school students had better English language achievement than students from semigovernment schools.

RQ3: Is there any significant impact of demographic factors, learning styles, and personality traits on English language achievement?

Table 7 shows the impact of demographic factors, learning styles, and personality traits on English language achievement. Before analyzing the data (stepwise regression), demographic factors were dummy coded. At 1st step, gender, school locations, and school types entered. These variables were accountable to 20.6\% variance of English language achievement. At the next step, learning styles were entered along with demographic factors. These variables explained $30.1 \%$ variance of the dependent variable. Last step, personality traits were entered along with demographic factors and learning styles. All these variables were accountable to $30.7 \%$ variance of the English language achievement. This Table also shows that multimodal learning style $(\mathrm{B}=1.20, \mathrm{SE}=0.13, \beta=0.33, \mathrm{p}<0.01$, $95 \% \mathrm{CI}$ of $\mathrm{B}[0.95,1.45])$ and extroversion personality trait $(\mathrm{B}=2.46, \mathrm{SE}=1.10$, $\beta=0.07, \mathrm{p}<0.05,95 \% \mathrm{CI}$ of $\mathrm{B}[0.31,4.61])$ were significant predictors of the English language achievement.

Table 6. Post-hoc test (LSD) results of learning styles and English language achievement by school types.

\begin{tabular}{|c|c|c|c|c|c|}
\hline \multirow{2}{*}{ School Type (I) } & \multirow{2}{*}{ School Type (J) } & \multirow{2}{*}{ MD (I-J) } & \multirow{2}{*}{$\mathrm{D}$} & \multicolumn{2}{|c|}{ 95\% Confidence Interva } \\
\hline & & & & Lower & Upper \\
\hline \multicolumn{6}{|c|}{ Auditory } \\
\hline \multirow{2}{*}{ Government } & Non-government & -0.05 & -0.03 & -0.46 & 0.36 \\
\hline & Semi-government & $0.79^{*}$ & 0.37 & 0.37 & 1.22 \\
\hline Non-government & Semi-government & $0.85^{\star}$ & 0.36 & 0.46 & 1.24 \\
\hline \multicolumn{6}{|c|}{ Read/Write } \\
\hline \multirow{2}{*}{ Government } & Non-government & -0.04 & -0.03 & -0.40 & 0.32 \\
\hline & Semi-government & $0.94^{*}$ & 0.50 & 0.57 & 1.31 \\
\hline Non-government & Semi-government & $0.98^{*}$ & 0.52 & 0.64 & 1.33 \\
\hline \multicolumn{6}{|c|}{ Kinesthetic } \\
\hline \multirow{2}{*}{ Government } & Non-government & -0.21 & -0.10 & -0.59 & 0.17 \\
\hline & Semi-government & $0.74^{*}$ & 0.37 & 0.34 & 1.13 \\
\hline Non-government & Semi-government & $0.94^{*}$ & 0.47 & 0.58 & 1.30 \\
\hline \multicolumn{6}{|c|}{ Multimodal } \\
\hline \multirow{2}{*}{ Government } & Non-government & 0.41 & 0.08 & -0.58 & 1.39 \\
\hline & Semi-government & $-2.72^{\star}$ & -0.52 & -3.74 & -1.70 \\
\hline Non-government & Semi-government & $-3.13^{\star}$ & -0.60 & -4.07 & -2.19 \\
\hline \multicolumn{6}{|c|}{ English Language Achievement } \\
\hline \multirow{2}{*}{ Government } & Non-government & $11.06^{*}$ & 0.53 & 7.51 & 14.60 \\
\hline & Semi-government & 1.91 & 0.11 & -1.76 & 5.58 \\
\hline Non-government & Semi-government & $-9.15^{\star}$ & -0.48 & -12.53 & -5.77 \\
\hline
\end{tabular}


Table 7. Regression result of English language achievement for gender, school location, school types, learning styles and personality traits.

\begin{tabular}{|c|c|c|c|c|c|c|c|c|}
\hline \multirow[t]{2}{*}{ Model } & \multicolumn{2}{|c|}{$\begin{array}{l}\text { Unstandardized } \\
\text { Coefficients }\end{array}$} & \multirow{2}{*}{$\begin{array}{c}\text { Standardized } \\
\text { Coefficients }\end{array}$} & \multicolumn{2}{|c|}{$\begin{array}{l}95.0 \% \text { Confidence } \\
\text { Interval for B }\end{array}$} & \multicolumn{3}{|c|}{ Correlations } \\
\hline & B & Std. Error & & Lower & Upper & Zero-order & Partial & Part \\
\hline \multicolumn{9}{|c|}{ Step 1: Model 1} \\
\hline Constant & 60.65 & 1.67 & & 57.36 & 63.91 & & & \\
\hline Gender & -0.32 & 1.50 & -0.01 & -3.26 & 2.62 & -0.09 & -0.01 & -0.01 \\
\hline U vs $R$ & -17.05 & 2.56 & $-0.26^{\star *}$ & -22.08 & -12.01 & -0.16 & -0.25 & -0.23 \\
\hline U vs SU & -19.13 & 2.25 & $-0.34^{\star *}$ & -23.54 & -14.72 & -0.37 & -0.31 & -0.29 \\
\hline G vs SG & 3.05 & 1.86 & 0.07 & -0.60 & 6.71 & 0.11 & 0.06 & 0.057 \\
\hline G vs NG & -4.94 & 1.86 & $-0.12^{* *}$ & -8.59 & -1.29 & -0.25 & -0.10 & -0.09 \\
\hline \multicolumn{9}{|c|}{ Step 2: Model 2} \\
\hline Constant & 53.80 & 1.72 & & 50.416 & 57.17 & & & \\
\hline Gender & 2.49 & 1.44 & 0.06 & -0.33 & 5.31 & -0.09 & 0.067 & 0.056 \\
\hline U vs $R$ & -17.27 & 2.41 & $-0.26^{* *}$ & -21.99 & -12.55 & -0.16 & -0.27 & -0.23 \\
\hline U vs SU & -15.11 & 2.15 & $-0.27^{* *}$ & -19.34 & -10.89 & -0.37 & -0.26 & -0.23 \\
\hline G vs SG & -0.17 & 1.78 & -0.00 & -3.66 & 3.317 & 0.109 & -0.004 & -0.00 \\
\hline G vs NG & -5.21 & 1.74 & $-0.13^{* *}$ & -8.64 & -1.79 & -0.25 & -0.12 & -0.10 \\
\hline $\mathrm{Mm}$ & 1.22 & 0.13 & $0.34^{* *}$ & 0.97 & 1.465 & 0.398 & 0.347 & 0.310 \\
\hline \multicolumn{9}{|c|}{ Step 3: Model 3} \\
\hline Constant & 45.69 & 3.99 & & 37.86 & 53.53 & & & \\
\hline Gender & 1.92 & 1.45 & 0.05 & -0.93 & 4.78 & -0.09 & 0.05 & 0.04 \\
\hline U vs R & -16.72 & 2.41 & $-0.25^{\star *}$ & -21.45 & -11.98 & -0.16 & -0.26 & -0.22 \\
\hline U vs SU & -14.79 & 2.15 & $-0.26^{\star *}$ & -19.01 & -10.57 & -0.37 & -0.26 & -0.22 \\
\hline G vs SG & -0.34 & 1.77 & -0.01 & -3.82 & 3.14 & 0.11 & -0.01 & -0.01 \\
\hline G vs NG & -5.15 & 1.74 & $-0.13^{* *}$ & -8.57 & -1.74 & -0.25 & -0.11 & -0.10 \\
\hline $\mathrm{Mm}$ & 1.20 & 0.13 & $0.33^{\star *}$ & 0.95 & 1.45 & 0.40 & 0.34 & 0.30 \\
\hline Exv & 2.46 & 1.10 & $0.07^{*}$ & 0.31 & 4.61 & 0.14 & 0.09 & 0.07 \\
\hline
\end{tabular}

${ }^{*} \mathrm{p}<0.05,{ }^{* *} \mathrm{p}<0.01 ; \mathrm{U}=$ Urban, $\mathrm{R}=$ Rural, $\mathrm{SU}=$ Semi-urban, $\mathrm{G}=$ Government, $\mathrm{SG}=$ Semi-government, $\mathrm{NG}=$ Non-government, $\mathrm{Mm}=$ Multimodal, Exv $=$ Extraversion; Model $1: \mathrm{R}^{2}=0.206$, Adjusted $\mathrm{R}^{2}=0.200$, $\mathrm{F}=34.679, \mathrm{p}<0.01$, effect size $=0.26$; predictors - Gender, Urban vs Rural, Urban vs Semi-urban, Government vs Semi-government, Government vs non-government; Model 2: $\mathrm{R}^{2}=0.301$, Adjusted $\mathrm{R}^{2}=0.295$, $\mathrm{F}=91.743, \mathrm{p}<0.01$, effect size $=0.43$; predictors-Gender, Government vs Non-government, Urban vs Rural, Urban vs Semi-urban, Government vs Semi-government, Multimodal; Model 3: $\mathrm{R}^{2}=0.307$, Adjusted $\mathrm{R}^{2}=0.299, \mathrm{~F}=5.062, \mathrm{p}<0.01$, effect size $=0.44$; predictors-Gender, Government vs Non-government, Urban vs Rural, Urban vs Semi-urban, Government vs Semi-government., Multimodal, Extraversion; Dependent variable: English Language Achievement.

\section{Discussion}

This cross sectional quantitative study was designed and accomplished to know the prevalence of the personality traits and learning styles among Bangladeshi EFL learners from secondary level of education. In addition, in view of academic achievement in EFL learning, relationship between students' gender with their 
personality traits and learning styles also been explored. The present study investigated the prevalence of personality traits for secondary level students and among the 676 respondents.

Exploratory research, such as personality is useful in examining the psychological difference between sex and the differences are often described in terms of gender having greater ratings on that characteristic, on average [38]. Women often find themselves more agreeable than males [39] \& [40]. This study also found that the highest mean $(3.79 \pm 0.54)$ for male EFL learner was observed for the personality traits Agreeableness and the lowest $(2.55 \pm 0.706)$ for the Neuroticism. For the female EFL learners the highest mean $(3.89 \pm 0.45)$ was observed for the personality traits Agreeableness and the lowest $(2.56 \pm 0.75)$ for the Neuroticism. The trait Agreeableness refers to more nurturing, tender-minded, and altruistic, more often, but gender differences do not imply that men and women only experience states on opposing ends of the trait spectrum [38].

Results indicate that among the respondents the highest portion (51.48\%) preferred to learn applying Multimodal learning styles and the lower portion $2.81 \%$ preferred to learn through Visual learning style. Besides, the rest of the respondents preferred to learn through Auditory, Read/Write and Kinesthetic, the rates were $19.82 \%, 8.28 \%$ and $17.60 \%$ respectively. Again, the highest mean for male EFL learner was observed for the learning styles Multimodal whereas for the female it was Auditory. Barbe \& Milone [41] conducted a research on 1000 elementary and high school learners and found that $30 \%$ were visual students, $25 \%$ were auditory learners, $15 \%$ were kinesthetic students, and the remaining $30 \%$ were a mixture of modalities. The highest mean $(6.35 \pm 5.90)$ for male EFL learner was observed for the learning styles Multimodal and the lowest mean $(1.74 \pm 1.65)$ for the Visual. For the female EFL learners, the highest mean $(3.79 \pm 2.14)$ was observed for the learning styles Auditory and the lowest (2.03 \pm 1.53 ) for the Visual. Wehrwein et al. [42] conducted a study, where they used VARK learning style inventory and found that maximum portion of male student's preferred multimodal instruction. The findings of the present study revealed that, there is a broad variety of student learning style preferences regardless of gender. This may be because the learners have come to terms with (or at least try to) embraced the teaching style, which is predominantly didactic lectures [22].

The findings show that multimodal has the highest mean value in rural areas than that of other areas, and it is lowest in semi-urban areas. Again, among all other learning styles the mean value of multimodal has higher value of semi-government school than that of other two type school. On the other hand, the mean value of visual learning is lowest in semi-government school among all other learning styles. The present study found that there exists variation between and within groups of learning style both in different school location and different school type as all the learning types are significance for ${ }^{*} \mathrm{p}<0.05$, ${ }^{*} \mathrm{p}<0.01$ except visual learning style for different school type.

Learning style relates to an individual preferential manner of absorbing, un- 
derstanding, and retaining data. This research also disclosed the meaning of the EFL learners' positive correlation between learning styles and academic results. The results of the study show that Multimodal has a statistically significant connection with academic achievement or grades of students. When learners preferred to obtain data in a multitude of modes, different learning techniques and strategies should be used to meet students' requirements. If a student has multiple (multimodal) learning styles, the benefits acquired through various learning methods include the capacity to learn faster and deeper in order to make recall more successful at a later date [43]. Again, the combination of learning methods can also lead to a more balanced attitude to study and learning, leading to higher understanding, understanding and retention. On the other side, in enhancing student success, it is very much indispensable to inculcate various approaches for student learning, hence, educators need to advance and enrich their teaching techniques [44]. Because of the better match between educator and learner styles, educators will reach more learners by using a range of teaching methods [22].

Pornsakulvanich et al. [27] acknowledged that the significant association between personality types and academic achievement in many research were reported. Traits of personality have a beneficial or negative effect on learners' academic accomplishment [4]. Nye et al. [28] investigated interrelations between psychological peculiarities, measured by Big Five model and their academic performances. The study found positive and significant correlation between the five personality traits and students' educational achievements. It has been discovered that personality traits are stronger predictors of academic, cognitive and effective performance [27]. Lounsbury et al. [45] also ascertained that all personality traits in middle and high school pupils were substantially associated with cognitive ability. Busato et al. [25] also found that the Big Five Personality Traits were positively correlated with academic success. These examples of studies show that there is a powerful link between personality types and academic accomplishment. This research discovered that extroversion is the best dimension between the five dimensions of personality that is strongly correlated with EFL learners' academic achievement. Perhaps the most identifiable personality traits of the Big-Five model is extraversion, whereas the person has energy, positive feelings, urgency, assertiveness, sociability and a tendency to seek stimulation in the business of others, and talk ability [46]. Extroverts incline to adapt new language more correctly than others because of greater communication abilities. Moreover, extroverts love interacting with individuals and are often viewed as completion of energy. They tend to be passionate, people focused on action. Again, they have high visibility in the group, like talking and asserting themselves, which may help them to improve them excel in EFL learning. Extroversion is associated with greater motivation to attain beneficial objectives [47] this may be the reason behind their better performance in learning English.

\section{Conclusion}

Helping their learners attain academic achievement has always been a significant 
issue of educators, teachers and administrators. The linguistic educators should study personality and learning style to provide an elated teaching-learning atmosphere by creating well-disposed teaching-learning approaches. In particular, extensive studies are available to show the connection between personality traits, learning styles, and academic performance. The language educators have countless explanations for understanding the logic of studying the learning styles as individuals have their own learning style. It is thought that each student acquires data in various respects and that no style of learning is superior to others. It is essential for each student to take complete advantage of their own learning style. If accommodated, our learning style can lead to enhanced teaching attitudes and increased productivity, academic achievement, and creativity. In addition, teachers should develop their own teaching styles and tactics to satisfy the distinct needs of the learners. EFL teachers and the school authority should make the parents aware about their children's learning style and personality trait so that they can provide more fruitful language learning environment at home for the learners.

\section{Delimitations and Recommendations}

Only mainstream secondary schools were chosen for this study. For time and budget constrain other junior secondary level institution such as Madrasah, English medium and vocational institutions were not taken under the preview of this study, which is a limitation of this research. Future research can confront with the different samples from other types of institutions, and then it could be possible to do a comparative analysis. Ample amount of training should be provided to the teachers, so that they can easily define the personality traits and learning styles of their students. It will help them to design an effective teaching-learning strategies for their students. The VARK questionnaire was not statistically validated. Educational researchers tried to discover a way to validate VARK. Unfortunately, they could not discover a satisfying statistical method, validating the VARK-based four-factor model [42].

\section{Scope of Further Study}

Further study can be done with larger samples and from general, technical and madrasah educational streams and more in-depth data can be collected for better understanding the situation. Moreover, a study can be done in exploring the importance of incorporating personality traits and learning style issues in the education of teachers in Bangladesh. Further study can be done in exploring the learning styles and personality traits of the teachers as it is observed in previous studies that these are significantly related to the academic excellence.

\section{Scope of Implication}

It has been shown through countless research that both low- and high-skill learners receive greater ratings on standardized performance exams when taught in their learning styles domain. Whatever learning styles learners prefer, know- 
ing their preferences in how they obtain data in their teaching may be useful to educators as well as helping learners perform efficiently in the classroom. Answers of the research questions are highly anticipated to offer educators some idea of improving the country's situation in terms of EFL teaching and learning not only in the country context but in other non-native context as well. Teachers teaching strategies have a great impact on students learning as well. Teachers' development program would be helpful for developing their capabilities to distinguish the individual differences so that they can design an effective motivational as well as teaching strategies. Moreover, teachers understanding about the learning styles of the learners would open the door to the possibilities for ameliorate the students' learning potential and their attitudes toward learning. In traditional EFL classrooms of the country, teacher, mostly uses the lecture method in some cases they allow students to do some reading /writing tasks. The findings of this study give an insight that it is time to revise the teaching strategies of the teachers. Teachers have to be more conscious about students' personality development issues as the majority of the students belong to agreeableness whereas extroverts are performing better when it considered the academic achievement.

\section{Conflicts of Interest}

The author declares no conflicts of interest regarding the publication of this paper.

\section{References}

[1] Komarraju, M., Karau, S.J., Schmeck, R.R. and Avdic, A. (2011) The Big Five Personality Traits, Learning Styles, and Academic Achievement. Personality and Individual Differences, 51, 472-477. https://doi.org/10.1016/j.paid.2011.04.019

[2] Cherry, K. (2016) The Big Five Personality Traits. https://www.verywell.com/the-big-five-personality-dimensions-2795422

[3] Ibrahimoglu, N., Yousuf, N.H., Razzak, N.A. and Norshahidi, N.D. (2014) A Meta-Analysis of the Relationship between Big Five Personality Traits and Students' Academic Achievement. Social Science Research ICSSR, Kota Kinabalu, Sabah.

[4] Eyong, E., David, B. and Umoh, A. (2014) The Influence of Personality Trait on the Academic Performance of Secondary School Students in Cross River State, Nigeria. IOSR Journal of Humanities and Social Science, 19, 12-19. https://doi.org/10.9790/0837-19311219

[5] Chamorro-Premuzic, T. and Furnam, A. (2006) Intellectual Competence and the Intelligent Personality: A Third Way Differential Psychology. Review of General Psychology, 10, 251-267. https://doi.org/10.1037/1089-2680.10.3.251

[6] Ibrahim, N.S., Yusof, N.S.H.C., Razzak, N.F.A. and Norshahidi, N.D. (2014) A Meta-Analysis of the Relationship between Big Five Personality Traits and Students' Academic Achievement. ICSSR E-Journal of Social Science Research, 2, 15-22.

[7] Ibrahimoglu, N., Unaldi, I., Samancioglu, M. and Baglibel, M. (2013) The Relationship between Personality Traits and Learning Styles: A Cluster Analysis. Asian Journal of Management Sciences and Education, 2, 93-108. 
[8] Mynatt, C.R. and Doherty, M.E. (2002) Understanding Human Behavior. 2nd Edition, Allyn \& Bacon, Boston.

[9] Dörnyei, Z. and Skehan, P. (2005) Individual Differences in Second Language Learning. In: Doughty, C. and Long, M., Eds., The Handbook of Second Language, Blackwell, Oxford, 589-639. https://doi.org/10.1002/9780470756492.ch18

[10] Gosling, S.D., Rentfrow, P.J. and Swann Jr., W.B. (2003) A Very Brief Measure of the Big-Five Personality Domains. Journal of Research in Personality, 37, 504-528. https://doi.org/10.1016/S0092-6566(03)00046-1

[11] Maghsoudi, M., Fatemeh, S. and Fatemeh, A. (2013) Investigating the Effect of Big Five Personality Traits in Iranian EFL Bilingual Learners. International Journal of Language and Linguistics, 1, 26-32. https://doi.org/10.11648/j.ijll.s.20130101.15

[12] Goldberg, L.R. (1990) An Alternative "Description of Personality": The Big-Five Factor Structure. Journal of Personality and Social Psychology, 59, 1216-1229. https://doi.org/10.1037//0022-3514.59.6.1216

[13] Alqunayeer, H.S. and Zamir, S. (2015) Identifying Learning Styles in EFL Classroom. International Journal of Learning and Teaching, 1, 82-87. https://doi.org/10.18178/ijlt.1.2.82-87

[14] Fleming, N.D. and Mills, C. (1992) Not Another Inventory, Rather a Catalyst for Reflection. To Improve the Academy, 11, 137-155. https://doi.org/10.1002/j.2334-4822.1992.tb00213.x

[15] Fleming, N.D. (2001) Teaching and Learning Styles: VARK Strategies. Neil Fleming, Christchurch.

[16] Paunonen, S.V. and Jackson, D.N. (2000) What Is beyond the Big Five? Plenty! Journal of Personality, 68, 821-835. https://doi.org/10.1111/1467-6494.00117

[17] Asghari, A., Fatemi, A.H. and Pishgha, R. (2012) Attribution Theory and Personality Traits among EFL Learners. International Journal of Linguistics, 4, 229-243. https://doi.org/10.5296/ijl.v4i2.1451

[18] Ehrman, M.E. (1995) Language Aptitude, Personality, and Language Learning: Is There a Link? AA4L Convention, Long Beach.

[19] Oxford, R. and Nyikos, M. (1989) Variables Affecting Choice of Language Learning Strategies by University Students. Modern Language Journal, 73, 291-300. https://doi.org/10.1111/j.1540-4781.1989.tb06367.x

[20] Oxford, R.L. (1992) Who Are Our Students? A Synthesis of Foreign and Second Language Research on Individual Differences with Implications for Instructional Practice. TESL Canada Journal/ Revue TESL Du Canada, 9, 30-49. https://doi.org/10.18806/tesl.v9i2.602

[21] Yufrizal, H. and Holiday, L. (2011) Learning Styles and University Students' Language Proficiency in Indonesia. International Conference on Teaching \& Learning in Higher Education.

[22] Shah, K., Ahmed, J. and Shenoy, N. (2013) How Different Are Students and Their Learning Styles? International Journal of Research in Medical Sciences, 1, 212-215. https://doi.org/10.5455/2320-6012.ijrms20130808

[23] Rofi'i, A. (2017) A Comparative Analysis on Extrovert and Introvert Students towards Their Speaking Skill. ETERNAL (English Teaching Journal), 8, 34-41. https://doi.org/10.26877/eternal.v8i2.3046

[24] Sadeghi, N., Kasim, Z.M., Tan, B.H. and Abdullah, F.S. (2012) Learning Styles, Personality Types and Reading Comprehension Performance. English Language Teaching, 5, 116. https://doi.org/10.5539/elt.v5n4p116 
[25] Busato, V.V., Prins, F.J., Elshout, J.J. and Hamakera, C. (2000) Intellectual Ability, Learning Style, Personality, Achievement Motivation and Academic Success of Psychology Students in Higher Education. Personality and Individual Differences, 29, 1057-1068. https://doi.org/10.1016/S0191-8869(99)00253-6

[26] Yanardöner, E., Kiziltepe, Z., Seggie, F.N. and Sekerler, S.A. (2014) The Learning Styles and Personality Traits of Undergraduates: A Case at a State University in Istanbul. The Anthropologist, 18, 591-600.

https://doi.org/10.1080/09720073.2014.11891577

[27] Pornsakulvanich, V., Dumrongsiri, N., Sajampun, P., Sornsri, S., John, S.P., Sriyabhand, T., Nuntapanich, C., Chantarawandi, C., Wongweeranoncha, P. and Jiradilok, S. (2012) An Analysis of Personality Traits and Learning Styles as Predictors of Academic Performance. ABAC Journal, 32, 1-19.

[28] Nye, J.V., Orel, E. and Kochergina, E. (2013) Big Five Personality Traits and Academic Performance in Russian Universities. https://doi.org/10.2139/ssrn.2265395

[29] Crystal, D. (1997) English as a Global Language. Cambridge University Press, Cambridge.

[30] Graddol, D. (1997) The Future of English. The British Council, London.

[31] Ahmed, S. (2012) English Language Teaching at Secondary School Level in Bangladesh: An Overview of the Implementation of Communicative Language Teaching Method. Journal on English Language Teaching, 2, 16-27. https://doi.org/10.26634/jelt.2.3.1961

[32] Al-Qaisy, L.M. and Khuffash, S.R. (2012) Relation between Personality Traits and Academic Achievement among University Students. Journal of Educational and Social Research, 2, 121-129.

[33] Kothari, C.R. (2019) Research Methodology: Methods and Techniques. 4th Edition, New Age International Publishers, New Delhi.

[34] Muijs, D. (2010) Doing Quantitative Research in Education with SPSS. 2nd Edition, SAGE Publications, London. https://doi.org/10.4135/9781849203241

[35] BANBEIS (2018) Bangladesh Education Statistics Report. Ministry of Education, Government of the Peoples Republic of Bangladesh, Dhaka.

[36] John, O.P. and Srivastava, S. (1999) The Big Five Trait Taxonomy: History, Measurement, and Theoretical Perspectives. In: Pervin, L.A. and John, O.P., Eds., Handbook of Personality: Theory and Research, Guilford Press, New York, 102-138.

[37] John, O.P., Naumann, L.P. and Soto, C.J. (2008) Paradigm Shift to the Integrative Big Five Trait Taxonomy: History, Measurement, and Conceptual Issues. In: John, O.P., Robins, R.W. and Pervin, L.A., Eds., Handbook of Personality. Theory and Research, The Guilford Press, New York, 114-158.

[38] Weisberg, Y.J., DeYoung, C.G. and Hirsh, J.B. (2011) Gender Differences in Personality across the Ten Aspects of the Big Five. Frontiers in Psychology, 2, Article 178. https://doi.org/10.3389/fpsyg.2011.00178

[39] Feingold, A. (1994) Gender Differences in Personality: A Meta-Analysis. Psychological Bulletin, 116, 429-456. https://doi.org/10.1037//0033-2909.116.3.429

[40] Costa, P.T., Terracciano, A. and McCrae, R.R. (2001) Gender Differences in Personality Traits across Cultures: Robust and Surprising Findings. Journal of Personality and Social Psychology, 81, 322-331. https://doi.org/10.1037//0022-3514.81.2.322

[41] Barbe, W.B. and Milone, M.N.J. (1981) What We Know about Modality Strengths. Educational Leadership, 38, 378-380.

[42] Wehrwein, E.A., Lujan, H.L. and DiCarlo, S.E. (2007) Gender Differences in Learn- 
ing Style Preferences among Undergraduate Physiology Students. Advances in Physiology Education, 31, 153-157. https://doi.org/10.1152/advan.00060.2006

[43] VARK: A Guide to Learning Styles. http://vark-learn.com

[44] Zhu, H.-R., Zeng, H., Zhang, H., Zhang, H.-Y., Wan, F.-J., Guo, H.-H. and Zhang, C.-H. (2018) The Preferred Learning Styles Utilizing VARK among Nursing Students with Bachelor Degrees and Associate Degrees in China. Acta Paulista de Enfermagem, 31, 162-169. https://doi.org/10.1590/1982-0194201800024

[45] Lounsbury, J.W., Welsh, D.P., Gibson, L.W. and Sundstrom, E. (2005) Broad and Narrow Personality Traits in Relation to Cognitive Ability in Adolescents. Personality and Individual Differences, 38, 1009-1019. https://doi.org/10.1016/j.paid.2004.06.022

[46] Atkinson, R.L., Richard, C.A., Edward, E.S., Daryl, J.B. and Susan, N.-H. (2000) Hilgard's Introduction to Psychology. Harcourt College Publishers, Orlando, 437.

[47] Wilmot, M.P., Wanberg, C.R., Kammeyer-Mueller, J.D. and Ones, D.S. (2019) Extraversion Advantages at Work: A Quantitative Review and Synthesis of the Meta-Analytic Evidence. Journal of Applied Psychology.

https://doi.org/10.1037/apl0000415 